\author{
Abstracta Iranica \\ Abstracta Iranica Revue bibliographique pour le domaine irano-aryen \\ Volume 32-33 | 2013 \\ Comptes rendus des publications de 2009-2010
}

\title{
N. Schindel. Sylloge Nummorum Sasanidarum / Israel
}

\section{Rika Gyselen}

\section{(2) OpenEdition}

\section{Journals}

\section{Édition électronique}

URL : http://journals.openedition.org/abstractairanica/40579

DOI : 10.4000/abstractairanica.40579

ISSN : 1961-960X

Éditeur :

CNRS (UMR 7528 Mondes iraniens et indiens), Éditions de l'IFRI

Édition imprimée

Date de publication : 1 décembre 2013

ISSN : 0240-8910

\section{Référence électronique}

Rika Gyselen, « N. Schindel. Sylloge Nummorum Sasanidarum / Israel », Abstracta Iranica [En ligne], Volume 32-33 | 2013, document 201, mis en ligne le 01 juillet 2016, consulté le 27 septembre 2020. URL : http://journals.openedition.org/abstractairanica/40579; DOI : https://doi.org/10.4000/ abstractairanica.40579

Ce document a été généré automatiquement le 27 septembre 2020.

Tous droits réservés 


\title{
N. Schindel. Sylloge Nummorum Sasanidarum / Israel
}

\author{
Rika Gyselen
}

\section{RÉFÉRENCE}

N. Schindel. Sylloge Nummorum Sasanidarum / Israel. Wien, Österreichische Akademie der Wissenschaften, 2009. 175 p. [Veröffentlichungen der numismatischen Kommission, Band 46]

1 L'objectif du projet de la "Sylloge Nummorum Sasanidarum" est de publier intégralement des collections de monnaies sassanides et arabo-sassanides, ce qui devrait permettre d'établir d'ici quelques années un corpus qui fait actuellement défaut dans cette discipline. La première série de la SNS traite des collections de Paris (Cabinet des Médailles, Bibliothèque nationale de France), de Berlin (Münzkabinett, Staatliche Museen zu Berlin) et de Vienne (Münzkabinett, Kunsthistorisches Museum).

2 Le présent volume est consacré aux collections (monnaies sassanides et arabosassanides, ainsi que les monnayages du Tabaristan et Bukhara) des Hebrew University, Israel Antiquity Authority et Israel Museum de Jérusalem, et celle du Kadman Numismatic Pavilion, Eretz Israel Museum de Tel Aviv. En appendice figure l'inventaire d'un trésor monétaire de monnaies de cuivre d'époque sassanide tardive conservé au Eretz Israel Museum de Tel Aviv.

3 Après un bref historique de ces diverses collections par chaque responsable local, sont passées en revue et commentées les monnaies qui apportent des données nouvelles. Suit une étude minutieuse du trésor de 1842 monnaies de cuivre de petit module qui par son nombre permet d'envisager maintenant une production substantielle de monnaies de cuivre à l'époque sassanide tardive.

4 Le catalogue comprend une typologie générale et succincte des différentes séries monétaires, la liste des légende monétaires pehlevies et arabes en translittération, transcription et traduction et un aperçu des éléments iconographiques additionnels. Le 
catalogue des collections est présenté sous forme de sylloge, c'est-à-dire le texte et les photos sont placés en vis-à-vis. Pour le trésor monétaire, la description et les images forment deux parties distinctes. Indices et bibliographie clôturent le volume.

\section{AUTEURS}

\section{RIKA GYSELEN}

CNRS/Mondes iranien et indien, Paris 